\title{
Sentinel lymph node biopsy versus selective neck dissection in patients with early oral squamous cell carcinoma: a cost analysis
}

\author{
Quitterie de Kerangal ${ }^{1}$, Raissa Kapso ${ }^{1}$, Stephane Temam ${ }^{1}$, Jean-Marie Gouin ${ }^{2}$, Jamila \\ Marghadi $^{1}$, Sylvain Moriniere ${ }^{3}$, Boris Laure ${ }^{4}$, François Bidault ${ }^{1}$, Odile Casiraghi ${ }^{1}$, Julia \\ Bonastre $^{1}$, and Antoine Moya-Plana ${ }^{1}$ \\ ${ }^{1}$ Gustave Roussy \\ ${ }^{2}$ Regional University Hospital Centre Tours \\ ${ }^{3} \mathrm{CHU}$ Bretonneau \\ ${ }^{4} \mathrm{CHRU}$ Tours
}

July 21, 2020

\begin{abstract}
Objective: Sentinel lymph node biopsy (SLNB) seems as efficient as selective neck dissection (SND) for the treatment of occult metastases in T1-T2cN0 oral squamous cell carcinoma (SCC). The aim of our study was to assess and compare the cost of these two surgical procedures. Patients and methods: This retrospective cost analysis includes consecutive patients treated between 2012 and 2017 in two French hospitals either by SLNB or SND. Hospital cost (hospital stay for initial surgery and re-hospitalizations over a period of 60 days after the initial surgery), the length of hospital stay for the initial surgery and the perioperative management were described and compared between the two techniques. The propensity score regression adjustment method was used to address selection bias. Results: Ninety-four patients underwent SLNB procedure and seventyseven patients underwent SND. The length of hospital stay for initial surgery was lower in SLNB group: 5.8 days (SD: 3.8) versus 9.2 days (SD: 5) in the SND group. Hospital costs were lower in SLNB group: \euro7 489 (standard deviation: \euro3 691) versus \euro8 886 (standard deviation: \euro4 381) but this difference was not significant after propensity score regression adjustment. The rate of complication, the delay of full oral feeding and postoperative drainage were lower in SLNB group. Conclusion: SLNB in T1-T2cN0 oral SCC is less invasive than SND with fewer complications, a shorter length of hospital stay and favorable perioperative management. This study shows that this technique could be also less expensive than SND.
\end{abstract}

\section{Hosted file}

Manuscript.doc available at https://authorea.com/users/344638/articles/471073-sentinellymph-node-biopsy-versus-selective-neck-dissection-in-patients-with-early-oral-squamouscell-carcinoma-a-cost-analysis

\section{Hosted file}

Table 1.docx available at https://authorea.com/users/344638/articles/471073-sentinel-lymphnode-biopsy-versus-selective-neck-dissection-in-patients-with-early-oral-squamous-cellcarcinoma-a-cost-analysis

\section{Hosted file}

Table 2.docx available at https://authorea.com/users/344638/articles/471073-sentinel-lymphnode-biopsy-versus-selective-neck-dissection-in-patients-with-early-oral-squamous-cellcarcinoma-a-cost-analysis 


\section{Hosted file}

Figure 1.docx available at https://authorea.com/users/344638/articles/471073-sentinel-lymphnode-biopsy-versus-selective-neck-dissection-in-patients-with-early-oral-squamous-cellcarcinoma-a-cost-analysis

\section{Hosted file}

Table 3.docx available at https://authorea.com/users/344638/articles/471073-sentinel-lymphnode-biopsy-versus-selective-neck-dissection-in-patients-with-early-oral-squamous-cellcarcinoma-a-cost-analysis

\section{Hosted file}

Table 4.docx available at https://authorea.com/users/344638/articles/471073-sentinel-lymphnode-biopsy-versus-selective-neck-dissection-in-patients-with-early-oral-squamous-cellcarcinoma-a-cost-analysis

\section{Hosted file}

Table 5.docx available at https://authorea.com/users/344638/articles/471073-sentinel-lymphnode-biopsy-versus-selective-neck-dissection-in-patients-with-early-oral-squamous-cellcarcinoma-a-cost-analysis 